\title{
On translating linguocultural lacunae in English media discourse
}

\author{
N. I. Liutianska \\ Petro Mohyla Black Sea National University, Mykolaiv, Ukraine \\ Corresponding author. E-mail: natalka.lyutyanska@gmail.com
}

Paper received 31.05.19; Accepted for publication 13.06.19.

\section{https://doi.org/10.31174/SEND-HS2019-199VII33-08}

\begin{abstract}
The present article deals with the concept and features of linguocultural lacunae as culturally specific lexis. The definition of the term "lacunae" is given as well as its different types are mentioned. Moreover, the paper aims to analyse all the possible ways for translating linguocultural lacunae in English media discourse. The latter was chosen because of some culturally specific phenomena present in it.
\end{abstract}

Keywords: translation, linguocultural, lacunae, non-equivalent lexis, cultureme, realia, media discourse.

Introduction. Recent researches of linguists show their interest in studying both language and cultural issues, thus developing a branch that is called linguocultural studies. The latter is characterized by investigating traditional issues, e.g. interrelationship between culture and language, as well as new ones. Language concepts and culture, nonequivalence and lexical gaps, semantics and pragmatics of language signs can be enumerated here.

This article focuses on translating non-equivalence lexis and lexical gaps, as their translation is very difficult because of the obstacles they create. Reaching mutual understanding between representatives of different cultures becomes impossible in the process of communication. Thus, knowing the specifics of such lexis is of great importance.

The notion of lacunae was first suggested with reference to the gaps in a text, represented by non-equivalent lexical units and other culture-bound items in the FrenchCanadian School [10]. Then it was developed in Russia by Sorokin, Markovina and other scholars [5, p. 166].

At the beginning, the term "lacuna" was used in translation studies and stylistics [10]. However, nowadays it is used in various areas of research [7].

Besides the term "lacunae" there are different terms denoting specific phenomena for some peculiar culture. They are "cultureme" [6], "non-equivalent lexis" [3], "realia" [1] and so on.

The term "cultureme" is considered as a sign of culture that also has a linguistic expression [2]. Some scholars regard "non-equivalent lexis" as a synonym of realia [1] whereas others consider non-equivalent items of vocabulary as the words that due to cultural difference do not exist in the other language [8].

It should be mentioned that linguocultural lacunae can be defined as notions which refer to national phenomena and belong to peculiar linguocultural community.

Different types of lacunae can be distinguished. They depend on several factors. Thus, lexical, phraseological, grammatical and stylistic lacunae can be enumerated here [4]. They are all of different origin.

Lexical lacunae emerge when words denoting objects of the target language lack in the source language.

Phraseological lacunae occur due to some differences in the phraseology of two languages.

Grammatical lacunae become possible because of different categories and different verbalization of the image of the world.
Stylistic lacunae arise when there is lack of elements with the same stylistic colouring in two different languages.

The further stage of our research devoted to linguocultural lacunae requires involvement of methods relevant and corpus necessary for its conducting.

Methods and corpus. Media texts and their translated versions taken from the Internet form the basis of the current research. They deal with different topics, e.g. politics, society, education and so on.

The present research was conducted in the framework of functional method and method of comparative analysis. The first one was used in order to study functions performed by linguocultural lacunae in the media discourse. The second one was used to compare the source texts with their target variants.

Results and discussion. Nowadays media discourse is a leading means of describing different events in the life of linguocultural communities, namely British and American. It is realized in the form of media texts.

Translation process of English media texts requires good knowledge of the English language as well as British and American culture. Thus, it is connected with linguocultural studies which focus its attention on culturally specific notions. The latter can complicate the process of translation as there are some cases when the target language lacks the signified object. Moreover, in certain cases it is necessary to convey not only the meaning of the separate notion, but also its national and historic colouring.

English media texts are the source of linguocultural lacunae, since they spread information specific to some peculiar linguocultural community, namely British or American people.

There are some possible ways to translate linguocultural lacunae. Let us consider the most widespread of them:

- transcription or transliteration: "Congress" in Ukrainian «Конгрес», "Senate" in Ukrainian «Сенат»;

- $\quad$ calque: "federal government" in Ukrainian «федеральний уряд», "the Oval Office” in Ukrainian «овальний кабінет»;

- descriptive translation: "Tory Cabinet Minister" in Ukrainian «член Ради міністрів від Консервативної партії Великої Британії», “boiler room” in Ukrainian «установа $з$ продажу незареєстрованих цінних паперів телефоном»;

- finding near analogues: "shopper" in Ukrainian «покупець», “mentor” in Ukrainian «керівник, вихова- 
тель», “think-tank” in Ukrainian «мозковий центр», «голова».

The first way, transcription as well as transliteration, was used to convey the graphic image of the lacunae or its sounding. Calque was used in order to convey the meaning of some terms that had similar meaning in the Ukrainian language. Descriptive translation was used to render the meaning of lacunae that did not have equivalents in the Ukrainian language. It was necessary to describe the meaning of such terms that were absent in the target lan- guage. And the last way was used to find the words with the almost similar meaning in the target language.

Overall, the results of this study show that the above mentioned ways are the most widespread while translating the linguocultural lacunae.

The present paper is helpful for further investigations in the field of linguocultural studies as it is connected with notions peculiar to some specific linguocultural communities as well as with their translation. In this case it was English-Ukrainian language pair.

\section{REFERENCES}

1. Влахов, С.И. и Флорин С.П. Непереводимое в переводе. Р.Валент, 2012.

2. Гак, В.Г. Языковые преобразования. Школа «Языки русской культуры», 1998.

3. Иванов, А. О. Безэквивалентная лексика. СПб., 2006.

4. Кшеновская, У.Л. Языковые лакуны в публицистическом тексте и способы их элиминирования в процессе перевода. Вестник Новосибирского государственного педагогического университета, №4(32), 2016, сс. 154-166.

5. Anokhina, Tetiana. 2013. The linguistic lacunion: cognitive mapping in schemes and terms. Journal of Education, Culture and Society, 1, pp.166-174.

6. Ganoshenko, Y. Culturemes and non-equivalent lexis in dictionaries, Institutional Repository of Zaporizhzhia State Medical University, $20 \quad$ May 2019,

dspace.zsmu.edu.ua/bitstream/123456789/3989/1/Ganoshenk o_Culturemes\%20and\%20nonequivalent\%201exis\%20in\%20dictionaries.pdf

7. Hall, J. Teaching and researching language and culture. Longman, 2002.

8. Podolej, M. Culture in bilingual dictionaries: Analysis of cultural content and culture-specific vocabulary in E-P-E dictionaries. The Faculty of English, Adam Mickiewcz University, 25 May 2019, iwa.amu.edu.pl/wa/files/Podolej.pdf

9. Sorokin, Yuriy A., and Iryne Y. Markovina. Culture and text. The introduction to lacunology. GEOTAR-Media, 2010.

10. Vinay, Jean P., and Jean Darbelnet. Stylistique comparée du français et de l'anglais: méthode de traduction. Nouvelle édition revue et corrigée. Didier, 1958.

\section{REFERENCES}

1. Vlakhov, S.I. and Florin S.P. Neperevodimoye $v$ perevode (The Untranslatable in Translation). R. Valent, 2012.

2. Gak, V.G. Yazykovyye preobrazovaniya (Language Transformations). Shkola "Yazyki russkoi kultury", 1998.

3. Ivanov, A.O. Bezekvivalentnaya leksika (Non-equivalent Lexis). Saint Petersburg, 2006.

4. Kshenovskaya, U.L. Yazykovyye lakuny v publitsisticheskom tekste i sposoby ikh eliminirovaniya $\mathrm{v}$ protsesse perevoda (Language lacunae in journalistic texts and ways of eliminating them in translation). Novosibirsk State Pedagogical University Bulletin, №4 (32), 2016, cc. 154-166.

5. Anokhina, Tetiana. 2013. The linguistic lacunion: cognitive mapping in schemes and terms. Journal of Education, Culture and Society, 1, pp.166-174.

6. Ganoshenko, Y. Culturemes and non-equivalent lexis in dictionaries, Institutional Repository of Zaporizhzhia State Med-

ical

University,

20

May

2019 , dspace.zsmu.edu.ua/bitstream/123456789/3989/1/Ganoshenk o_Culturemes\%20and\%20nonequivalent $\% 201$ exis $\% 20$ in $\% 20$ dictionaries.pdf

7. Hall, J. Teaching and researching language and culture. Longman, 2002.

8. Podolej, M. Culture in bilingual dictionaries: Analysis of cultural content and culture-specific vocabulary in E-P-E dictionaries. The Faculty of English, Adam Mickiewcz University, 25 May 2019, iwa.amu.edu.pl/wa/files/Podolej.pdf

9. Sorokin, Yuriy A., and Iryne Y. Markovina. Culture and text. The introduction to lacunology. GEOTAR-Media, 2010.

10. Vinay, Jean P., and Jean Darbelnet. Stylistique comparée du français et de l'anglais: méthode de traduction. Nouvelle édition revue et corrigée. Didier, 1958. 